\title{
Development and Evaluation of Anti-Inflammatory Activity of Hibiscus Emulgel
}

\author{
B. Mounika ${ }^{1}$, I. Bala Tripura Sundari ${ }^{2}$. \\ ${ }^{1}$ M Pharmacy, Sri Venkateshwara College of Pharmacy, Osmania University, Hyderabad-81. \\ ${ }^{2}$ Assistant Professor, Sri Venkateshwara College of Pharmacy, Hyderabad-81. \\ Corresponding Author: B. Mounika \\ Sri Venkateshwara College of Pharmacy, Madhapur, Hyderabad-81.
}

\begin{abstract}
:
Objective: To formulate and evaluate anti-inflammatory activity of Hibiscus emulgel.

Methods: The emulsions of methanolic extract of Hibiscus were prepared by using different oils like light liquid paraffin, coconut oil, olive oil and by using varying concentrations of Tween80 and Span80. Based on the physicochemical characteristics the best selected emulsion was formulated into emulgel by using different gelling agents like Carbopol 934,HPMC E15, NaCMC in different ratios. Optimization of the prepared emulgel formulations was done based on for their physicochemical parameters and percentage drug release. Optimized formulation OEG4 was evaluated for Anti-inflammatory activity using carrageenaninduced rat paw oedema model.

Results: The present investigation shows the physicochemical characterization of prepared emulgels such as spread ability, viscosity, drug content, In vitro diffusion studies, stability studies. The stability studies were performed as per ICH guidelines at two different temperatures for 3 months i.e., room temperature $\left(25 \pm 2^{\circ} \mathrm{C} / 60+5 \% \mathrm{RH}\right)$ and $\left(40 \pm 2^{\circ} \mathrm{C} / 75+5 \% \mathrm{RH}\right)$. The drug content of the optimized formulation OEG4 was monitored for a period of 90days. The optimized emulgel formulation OEG4 was compared with Diclofenac sodium as a standard drug for evaluating theanti-inflammatory activity. The optimized formulation showed maximum inhibition of $85.46 \%$ was observed at $4 \mathrm{hrs}$ of administration. There was statistically significant reduction in paw edema by test gel $(\mathrm{p}<0.01)$ when compared with standard emulgel.

Conclusion: The present study concluded that Hibiscus emulgel showed potential anti-inflammatory activity.
\end{abstract}

Key Words: Carbopol934, HPMC E15, HPMC K4M, NaCMC, Hibiscus, Emulgel.

\section{INTRODUCTION}

Inflammation is a pathophysiological response of living tissues to injuries that leads to local accumulation of plasmatic fluid and blood cells. It is also a complex biological response of vascular tissues to harmful stimuli, such as pathogens, damaged cells or irritants. It is a protective attempt by the organism to remove the injurious stimuli and to initiate healing process. ${ }^{[1]}$ During the development of inflammation, the concentrated actions of molecular signalling determine whether inflammatory cells undergo migration, activation, proliferation, differentiation or clearance. ${ }^{[2]}$ Redness, heat, swelling, pain and loss of function are the five responses to tissue injury and are also called the cardinal signs of inflammation. ${ }^{[3]}$ Though these signs and symptoms are necessary for tissue repair, it can be noxious to people thus must be treated with drugs known as anti-inflammatory agents. As the available anti-inflammatory drugs (steroidal and non- 


\section{B. Mounika1, International Journal of Ayurvedic \&Herbal Medicine 9(2) Mar.-Apr. 2019 (3464-3476)}

steroidal) present a wide range of side effects, many studies are being directed to find anti inflammatory agents from natural sources. ${ }^{[4]}$ In this context, medicinal plants are widely used in folk medicine in many countries to treat different inflammatory conditions and skin inflammation. ${ }^{[5]}$

Hibiscus is a plant which belongs to the family Malvaceae, grows in tropical and sub tropical regions. Various parts of the plant were commonly used in folk medicine for wide variety of remedies. Various parts of the plant are used to treat diarrhoea, asthma, hypertension and insomnia.

It is found worthwhile to investigate the anti-inflammatory acivity of Hibiscus leaves which was not reported yet. Several tests on adult male wistar rats and albino mice using metanolic extracts of Hibiscus were conducted to confirm the anti-inflammatory activity. However, crude extracts cannot easily be administered to living organisms due to the dose, which may be too small, or may cause irritation if applied as it is.Formulation of dosage form is necessary for easy administration of leaf extract of Hibiscus.

Drug delivery through the skin has been a promising concept for long time because the skin is easy to acess, has a large surface area with vast exposure to the circulatory and lymphatic networks and the route is non-invasive. Tropical preparations such as creams, ointments, and gels may be prepared where it can be spread to local inflammation sites. Transdermal drug delivery systems are gaining in popularity in this aspect. The main limiting factor of transdermal drug delivery i.e., epidermal barrier can be overcome by gels when compared to transdermal dermal delivery. ${ }^{[6]}$

Therefore, the present study was aimed at formulating and investigating an effective antiinflammatory emulgel formulation of methanolic extract of Hibiscus leaves.

\section{MATERIALS AND METHODS:}

\section{Collection of Plant material and Preparation of extract:}

Mangiferaindica leaves were collected from local market, Hyderabad, India and were further authenticated by Dr. MadhavaChetty, Botanist, Tirupati, Andhra Pradesh. All the other solvents and reagents were of analytical grade. Fresh leaves of the plant were washed with water immediately after collection. These were chopped into small pieces, air dried at room temperature for 10 days, grounded in to fine powder and stored in air tight containers. Powder weighing 650 grams was macerated with 5 litres of pure methanol for 7 days at room temperature. Later it was filtered and the extract was concentrated under reduced pressure below $500 \mathrm{C}$ in rotary vacuum evaporator. It was kept in petri dish for air drying to remove the traces of methanol and finally a concentrated extract is formed. ${ }^{[7-8]}$.

\section{PREPARATION OF EMULGEL}

The preparation of emulsion, first the oil phase of the emulsion was prepared by dissolving Span80 in light liquid paraffin while the aqueous phase was prepared by dissolving Tween80 in purified water. Methyl paraben and Propyl paraben were dissolved in propylene glycol whereas extract was dissolved in water, by sonication and both the solutions were separately heated to $70-75^{\circ} \mathrm{C}$. Then the oily phase was added to the aqueous phase with continuous stirring until cooled to room temperature. The obtained emulsion was mixed with the gel. All the polymers (Carbopol 934, HPMC E15, and Na CMC) were used at the percentage of $0.5 \%-4 \%$ for the formulation of Emulgels. In this type of Emulgel preparation, the gels were formulated by dispersing $0.5,0.75,1 \%, 2 \%, 3 \%$ of different polymers in purified water with constant stirring by using homogenizer, $\mathrm{pH}$ of the gel was adjusted using Triethanolamine. 
B. Mounika1, International Journal of Ayurvedic \&Herbal Medicine 9(2) Mar.-Apr. 2019 (3464-3476)

Table -I : Preparation of Light liquid paraffin Emulsion

\begin{tabular}{|l|c|c|c|c|c|c|c|c|c|c|}
\hline Ingredients & LP1 & LP2 & LP3 & LP4 & LP5 & LP6 & LP7 & LP8 & LP9 & LP10 \\
\hline Liquid paraffin(ml) & 1 & 1.5 & 1 & 1.5 & 1.5 & 2 & 2.5 & 2 & 3 & 2.5 \\
\hline Tween80(ml) & 0.2 & 0.2 & 0.2 & 0.2 & 0.4 & 0.2 & 0.2 & 0.3 & 0.2 & 0.2 \\
\cline { 1 - 10 } Span80(ml) & 0.2 & 0.2 & 0.3 & 0.3 & 0.2 & 0.2 & 0.2 & 0.2 & 0.2 & 0.3 \\
\hline Water(up to 10ml) & q.s & q.s & q.s & q.s & q.s & q.s & q.s & q.s & q.s & q.s \\
\hline
\end{tabular}

Table-II: Preparation of Coconut oil Emulsion

\begin{tabular}{|l|c|c|c|c|c|c|c|c|c|c|}
\hline Ingredients & C1 & C2 & C3 & C4 & C5 & C6 & C7 & C8 & C9 & C10 \\
\hline Coconut oil(ml) & 1 & 1.5 & 1 & 2 & 2.5 & 3 & 2 & 2.5 & 3 & 2 \\
\hline Tween80(ml) & 0.2 & 0.2 & 0.2 & 0.2 & 0.2 & 0.2 & 0.3 & 0.3 & 0.3 & 0.3 \\
\hline Span80(ml) & 0.2 & 0.2 & 0.3 & 0.3 & 0.2 & 0.3 & 0.2 & 0.2 & 0.3 & 0.3 \\
\hline Water(up to 10ml) & q.s & q.s & q.s & q.s & q.s & q.s & q.s & q.s & q.s & q.s \\
\hline
\end{tabular}

Table-III :-Preparation of Olive oil Emulsion

\begin{tabular}{|l|c|c|c|c|c|c|c|c|c|c|}
\hline Ingredients & O1 & O2 & O3 & O4 & O5 & O6 & O7 & O8 & O9 & O10 \\
\hline Olive oil (ml) & 1 & 1.5 & 1.5 & 1.5 & 2 & 2.5 & 2 & 2.5 & 3 & 3 \\
\hline Tween80(ml) & 0.2 & 0.2 & 0.3 & 0.4 & 0.3 & 0.3 & 0.2 & 0.2 & 0.2 & 0.3 \\
\hline Span80(ml) & 0.2 & 0.2 & 0.3 & 0.3 & 0.3 & 0.2 & 0.2 & 0.2 & 0.3 & 0.3 \\
\hline Water(up to 10ml) & q.s & q.s & q.s & q.s & q.s & q.s & q.s & q.s & q.s & q.s \\
\hline
\end{tabular}

The optimized emulsions LP5, C3, O3 were named as LP (Liquid Paraffin), C(Coconut Oil) and O(Olive oil).

Table-IV: Formulation of Carbopo1934 (Light liquid paraffin) Emulgels (w/w \%)

\begin{tabular}{|l|c|c|c|c|c|}
\hline INGREDIENTS & LPEG1 & LPEG2 & LPEG3 & LPEG4 & LPEG5 \\
\hline Drug(mg) & 250 & 250 & 250 & 250 & 250 \\
\hline Liquid paraffin(ml) & 1.5 & 1.5 & 1.5 & 1.5 & 1.5 \\
\hline Tween80(ml) & 0.4 & 0.4 & 0.4 & 0.4 & 0.4 \\
\hline Span80(ml) & 0.2 & 0.2 & 0.2 & 0.2 & 0.2 \\
\hline Methyl paraben & 0.002 & 0.002 & 0.002 & 0.002 & 0.002 \\
\hline Propyl paraben & 0.003 & 0.003 & 0.003 & 0.003 & 0.003 \\
\hline Propyleneglycol(ml) & 1.5 & 1.5 & 1.5 & 1.5 & 1.5 \\
\hline Triethanolamine & q.s & q.s & q.s & q.s & q.s \\
\hline Carbopol934(gm) & 0.1 & 0.15 & 0.2 & 0.3 & 0.4 \\
\hline Water up to 20ml & q.s & q.s & q.s & q.s & q.s \\
\hline
\end{tabular}

Table-V: Formulation of HPMC E15 (Light liquid paraffin) Emulgels (w/w \%)

\begin{tabular}{|l|c|c|c|c|}
\hline INGREDIENTS & LPEG6 & LPEG7 & LPEG8 & LPEG9 \\
\hline Drug(mg) & 250 & 250 & 250 & 250 \\
\hline Liquid paraffin(ml) & 1.5 & 1.5 & 1.5 & 1.5 \\
\hline Tween80(ml) & 0.4 & 0.4 & 0.4 & 0.4 \\
\hline Span80(ml) & 0.2 & 0.2 & 0.2 & 0.2 \\
\hline Methyl paraben & 0.002 & 0.002 & 0.002 & 0.002 \\
\hline Propyl paraben & 0.003 & 0.003 & 0.003 & 0.003 \\
\hline Propylene glycol(ml) & 1.5 & 1.5 & 1.5 & 1.5 \\
\hline
\end{tabular}


B. Mounika1, International Journal of Ayurvedic \&Herbal Medicine 9(2) Mar.-Apr. 2019 (3464-3476)

\begin{tabular}{|l|c|c|c|c|}
\hline Triethanolamine(q.s) & q.s & q.s & q.s & q.s \\
\hline HPMC E15 & 0.2 & 0.25 & 0.3 & 0.4 \\
\hline Water up to $20 \mathrm{ml}$ & q.s & q.s & q.s & q.s \\
\hline
\end{tabular}

Table-VI: Formulation of Na CMC (Light liquid paraffin) Emulgels (w/w \%)

\begin{tabular}{|l|c|c|c|c|}
\hline INGREDIENTS & LPEG10 & LPEG11 & LPEG12 & LPEG13 \\
\hline Drug(mg) & 250 & 250 & 250 & 250 \\
\hline Liquid paraffin(ml) & 1.5 & 1.5 & 1.5 & 1.5 \\
\hline Tween80(ml) & 0.4 & 0.4 & 0.4 & 0.4 \\
\hline Span80(ml) & 0.2 & 0.2 & 0.2 & 0.2 \\
\hline Methyl paraben & 0.002 & 0.002 & 0.002 & 0.002 \\
\hline Propyl paraben & 0.003 & 0.003 & 0.003 & 0.003 \\
\hline Propylen glycol(ml) & 1.5 & 15 & 1.5 & 1.5 \\
\hline Triethanolamine(q.s) & q.s & q.s & q.s & q.s \\
\hline Na CMC(gm) & 1.5 & 2 & 2.5 & 3 \\
\hline Water up to 20ml & q.s & q.s & q.s & q.s \\
\hline
\end{tabular}

Table-VII: Formulation of Carbopo1934 (coconut oil) Emulgels (w/w \%)

\begin{tabular}{|l|c|c|c|c|c|}
\hline INGREDIENTS & CEG1 & CEG2 & CEG3 & CEG4 & CEG5 \\
\hline Drug(mg) & 250 & 250 & 250 & 250 & 250 \\
\hline Coconut oil(ml) & 01 & 01 & 01 & 01 & 01 \\
\hline Tween80(ml) & 0.2 & 0.2 & 0.2 & 0.2 & 0.2 \\
\hline Span80(ml) & 0.3 & 0.3 & 0.3 & 0.3 & 0.3 \\
\hline Methyl paraben & 0.002 & 0.002 & 0.002 & 0.002 & 0.002 \\
\hline Propyl paraben & 0.003 & 0.003 & 0.003 & 0.003 & 0.003 \\
\hline Propylen glycol(ml) & 1.5 & 1.5 & 1.5 & 1.5 & 1.5 \\
\hline Triethanolamine & q.s & q.s & q.s & q.s & q.s \\
\hline Carbopol934(gm) & 0.1 & 0.15 & 0.2 & 0.3 & 0.25 \\
\hline Water up to $20 \mathrm{ml}$ & q.s & q.s & q.s & q.s & q.s \\
\hline
\end{tabular}

Table -VIII: Formulation of Na CMC (Coconut oil) Emulgels (w/w \%)

\begin{tabular}{|l|c|c|c|c|}
\hline INGREDIENTS & CEG6 & CEG7 & CEG8 & CEG9 \\
\hline Drug(mg) & 250 & 250 & 250 & 250 \\
\hline Coconut oil(ml) & 1 & 1 & 1 & 1 \\
\hline Tween80(ml) & 0.2 & 0.2 & 0.2 & 0.2 \\
\hline Span80(ml) & 0.3 & 0.3 & 0.3 & 0.3 \\
\hline Methyl paraben & 0.002 & 0.002 & 0.002 & 0.002 \\
\hline Propyl paraben & 0.003 & 0.003 & 0.003 & 0.003 \\
\hline Propylene glycol(ml) & 1.5 & 15 & 1.5 & 1.5 \\
\hline Triethanolamine(q.s) & q.s & q.s & q.s & q.s \\
\hline Na CMC(gm) & 1.5 & 2 & 2.5 & 3 \\
\hline Water up to 20ml & q.s & q.s & q.s & q.s \\
\hline
\end{tabular}


B. Mounika1, International Journal of Ayurvedic \&Herbal Medicine 9(2) Mar.-Apr. 2019 (3464-3476)

Table-IX:Formulation of HPMC E15 (Coconut oil) Emulgels (w/w\%)

\begin{tabular}{|l|c|c|c|c|}
\hline INGREDIENTS & CEG10 & CEG11 & CEG12 & CEG13 \\
\hline Drug(mg) & 250 & 250 & 250 & 250 \\
\hline Coconut oil(ml) & 1 & 1 & 1 & 1 \\
\hline Tween80(ml) & 0.2 & 0.2 & 0.2 & 0.2 \\
\hline Span80(ml) & 0.3 & 0.3 & 0.3 & 0.3 \\
\hline Methyl paraben & 0.002 & 0.002 & 0.002 & 0.002 \\
\hline Propyl paraben & 0.003 & 0.003 & 0.003 & 0.003 \\
\hline Propylene glycol(ml) & 1.5 & 1.5 & 1.5 & 1.5 \\
\hline Triethanol amine(q.s) & q.s & q.s & q.s & q.s \\
\hline HPMC E15(gm) & 0.2 & 0.25 & 0.3 & 0.4 \\
\hline Water up to 20ml & q.s & q.s & q.s & q.s \\
\hline
\end{tabular}

Table -X: Formulation of carbopol934 (Olive oil) Emulgels (w/w \%)

\begin{tabular}{|l|l|l|l|l|l|}
\hline INGREDIENTS & OEG1 & OEG2 & OEG3 & OEG4 & OEG5 \\
\hline Drug(mg) & 250 & 250 & 250 & 250 & 250 \\
\hline Olive oil(ml) & 1.5 & 1.5 & 1.5 & 1.5 & 1.5 \\
\hline Tween80(ml) & 0.3 & 0.3 & 0.3 & 0.3 & 0.3 \\
\hline Span80(ml) & 0.3 & 0.3 & 0.3 & 0.3 & 0.3 \\
\hline Methyl paraben & 0.002 & 0.002 & 0.002 & 0.002 & 0.002 \\
\hline Propyl paraben & 0.003 & 0.003 & 0.003 & 0.003 & 0.003 \\
\hline Propylene glycol(ml) & 1.5 & 1.5 & 1.5 & 1.5 & 1.5 \\
\hline Triethanolamine & q.s & q.s & q.s & q.s & q.s \\
\hline Carbopol934(gm) & 0.1 & 0.15 & 0.2 & 0.3 & 0.4 \\
\hline Water up to20ml & q.s & q.s & q.s & q.s & q.s \\
\hline
\end{tabular}

Table -XI:Formulation of HPMC E15 Olive oil Emulgels (w/w \%)

\begin{tabular}{|l|c|c|c|c|}
\hline INGREDIENTS & OEG6 & OEG7 & OEG8 & OEG9 \\
\hline Drug(mg) & 250 & 250 & 250 & 250 \\
\hline Light liquid paraffin(ml) & 1 & 1 & 1 & 1 \\
\hline Tween80(ml) & 0.3 & 0.3 & 0.3 & 0.3 \\
\hline Span80(ml) & 0.3 & 0.3 & 0.3 & 0.3 \\
\hline Methyl paraben & 0.002 & 0.002 & 0.002 & 0.002 \\
\hline Propyl paraben & 0.003 & 0.003 & 0.003 & 0.003 \\
\hline Propylene glycol(ml) & 1.5 & 1.5 & 1.5 & 1.5 \\
\hline Triethanolamine(q.s) & q.s & q.s & q.s & q.s \\
\hline HPMC E15 & 0.2 & 0.25 & 0.3 & 0.4 \\
\hline Water up to20ml & q.s & q.s & q.s & q.s \\
\hline
\end{tabular}

Table -XIII:OPTIMIZED FORMULATIONS

\begin{tabular}{|l|c|c|c|}
\hline INGREDIENTS & LPEG4 & CEG3 & OEG4 \\
\hline Drug(mg) & 250 & 250 & 250 \\
\hline Light liquid paraffin(ml) & 1.5 & - & - \\
\hline Coconut oil(ml) & - & 01 & - \\
\hline Olive oil $(\mathrm{ml})$ & - & - & 1.5 \\
\hline
\end{tabular}


B. Mounika1, International Journal of Ayurvedic \&Herbal Medicine 9(2) Mar.-Apr. 2019 (3464-3476)

\begin{tabular}{|l|c|c|c|}
\hline Tween80(ml) & 0.4 & 0.2 & 0.3 \\
\hline Span80(ml) & 0.2 & 0.3 & 0.3 \\
\hline Methyl paraben & 0.002 & 0.002 & 0.002 \\
\hline Propyl paraben & 0.003 & 0.003 & 0.003 \\
\hline Propylene glycol(ml) & 1.5 & 1.5 & 1.5 \\
\hline Triethanolamine(q.s) & Q.S & Q.S & Q.S \\
\hline Caropol934(gm) & 0.3 & 0.2 & 0.3 \\
\hline Water up to20ml & q.s & q.s & q.s \\
\hline
\end{tabular}

\section{EVALUATION OF PREPARED EMULGELS}

Prepared Emulgels of Hibiscus were evaluated for physical examination parameters like colour, homogeneity, phase separation, determination of $\mathrm{pH}$, spreadability, viscosity, drug content, stability, in vitro diffusion studies.

Homogeneity:All developed Emulgels were tested for homogeneity by visual inspection after they have been set in the container. They were tested for their appearance and presence of any aggregates, particles and fibers.

Colour: The formulations were viewed for their visual appearance and for no colour change.

Determination of pH:pH was checked using $\mathrm{pH}$ meter (Systronics digital $\mathrm{pH}$ meter). The electrode was submersed into the formulations at room temperature and readings were noted.

Spreadability:The spreadability of the prepared formulations was determined by measuring the spreading diameter of $1 \mathrm{~g}$ of the Emulgel between $20 \times 20 \mathrm{~cm}$ glass plates after $1 \mathrm{~min}$. The mass of the upper plate was standardized at $125 \mathrm{~g}$. The spreadability was calculated using the formula $\mathrm{S}=\mathrm{M} . \mathrm{L} / \mathrm{T}$

Viscosity:Viscosity determinations of the prepared formulations were carried out by Brookfield Synchroelectric viscometer (LV-DV Pro II), Spindle S64 (Small sample adapter) and the angular velocity increased from 5, 10, 50, and 100rpm and results were noted.

Drug content:Drug content was estimated spectrometrically where $1 \mathrm{~g}$ of the formulation was taken and dissolved in 100ml of phosphate buffer $\mathrm{pH} 7.4$ and kept for shaking for 1-2 hrs. The solution was passed through the Whatmann filter paper no.42 and filtered. Appropriate dilutions were done if required and the drug content was measured spectrophotometerically against phosphate buffer $\mathrm{pH} 7.4$ at $278 \mathrm{~nm}$.

Stability Studies:The physical stability of the developed Emulgel formulations were performed according to the ICH guidelines. The optimized formulations were stored at two different temperature range for 3 months i.e., refrigerator conditions $\left(2-8 \pm 2^{0} \mathrm{C}\right)$ and room temperature $\left(25 \pm 2^{0} \mathrm{C}\right)$. Samples were withdrawn at 30, 60, 90 day time interval and checked for the percentage drug entrapment.

In-vitro diffusion studies:The drug release studies were carried out using modified diffusion apparatus in $250 \mathrm{ml}$ beaker containing $100 \mathrm{ml}$ Phosphate buffer. Phosphate buffer $\mathrm{pH} 7.4$ was placed in a $250 \mathrm{ml}$ beaker. The beaker was assembled on a magnetic stirrer and the medium was equilibrated at $37 \pm 0.5^{0} \mathrm{c}$. Dialysis membrane was taken and one end of the membrane was sealed. Emulgel was applied on the dialysis membrane and other end was closed. The dialysis membrane containing the sample was suspended in the medium. Aliquots were withdrawn $(5 \mathrm{ml})$ at specific intervals, filtered and the medium was immediately replaced with same quantity of fresh buffer solution. The Aliquots was measured for the amount of the drug by using UV spectrophotometer at $278 \mathrm{~nm}$. The cumulative drug release was calculated [9].

\section{RESULTS AND DISCUSSION}

Determination of $\lambda \max$ : The $\lambda \max$ of Hibiscus extract was determined in Phosphate buffer $\mathrm{pH}$ 7.4. $10 \mu \mathrm{g} / \mathrm{ml}$ of drug solution was scanning in the UV range. An absorption maximum of $278 \mathrm{~nm}$ was obtained as shown in fig 1.0 
B. Mounika ${ }^{1}$, International Journal of Ayurvedic \&Herbal Medicine 9(2) Mar.-Apr. 2019 (3464-3476)

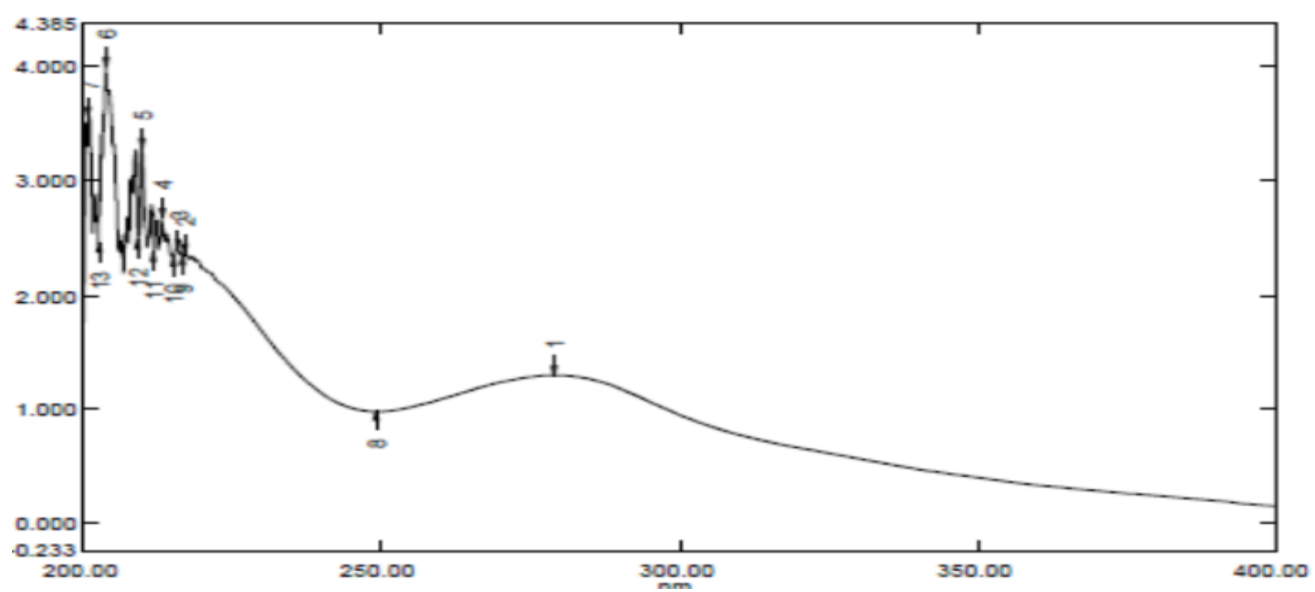

Fig 1.0: UV Scan of Hibiscus leaf extract

Standard Graph:The standard graph of Hibiscus extract by UV spectrophotometry at $278 \mathrm{~nm}$ is shown in theFig.1.1The linear regression equation is $y=0.0365$. The correlation co-efficient $\left(\mathrm{R}^{2}\right)$ of the regression line is 0.9929 .

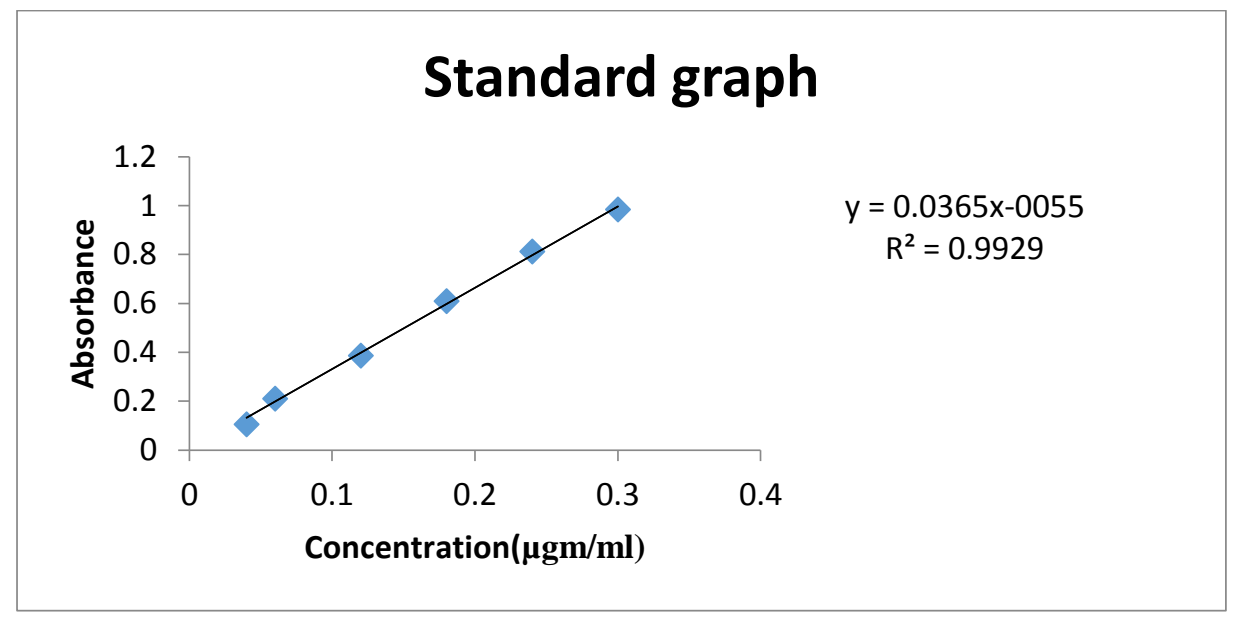

Fig1.1: Calibration curve of Hibiscus in $\mathrm{pH}$ 7.4 Phosphate Buffer.

Drug - Excipient compatibility studies:Drug -Excipient compatibility studies were carried out by Fourier Transform Infrared Spectroscopy analysis (Shimadzu 8400S). The IR spectrum of the pure drug was compared with IR spectrum of combination of drug and excipient and it was found that there were no specific interactions between the drug and excipient.

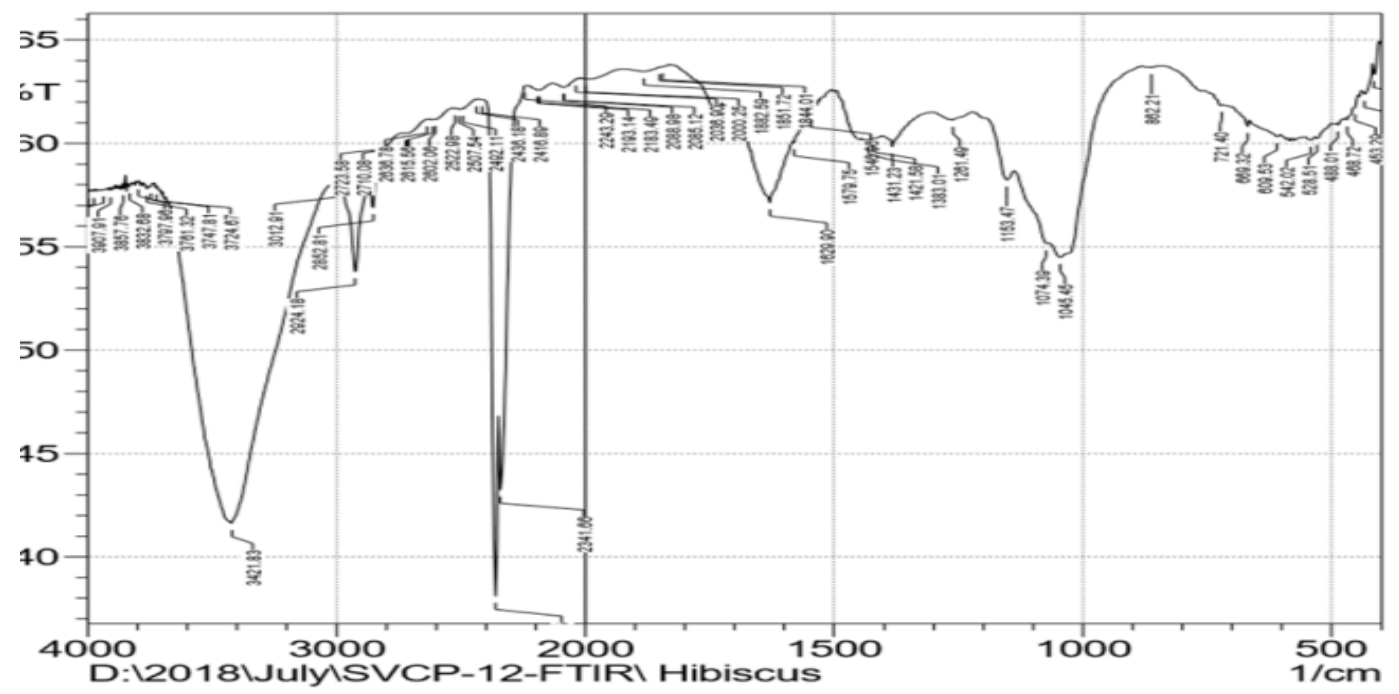

Fig no.1.2 FT-IR of hibiscus 
(9) SHMadzu

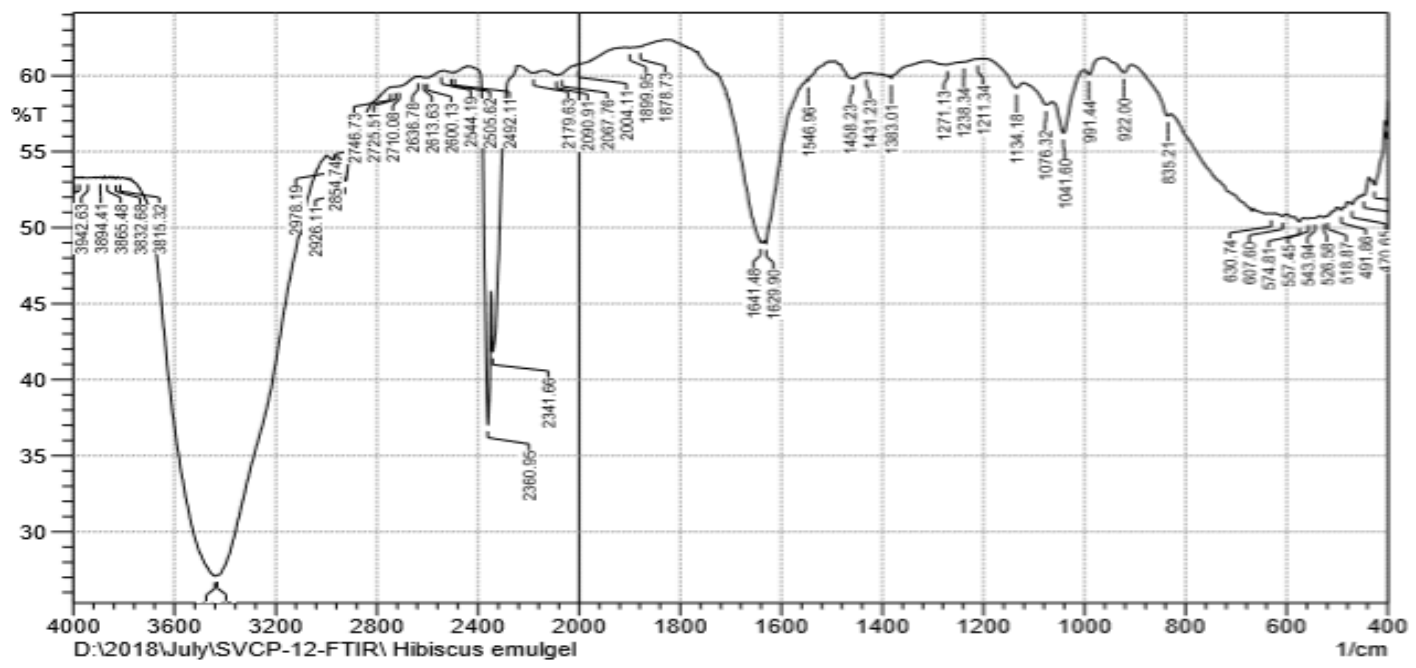

Fig no.1.3 FT-IR of optimized formulation

Table no XIV: Functional groups of Drug-Excipient compatibilities

\begin{tabular}{|c|c|c|}
\hline Functional group & Observed functional group in drug & Observed functional group in emulgel \\
\hline $\mathrm{C}=\mathrm{C}$ & 1629.9 & 1629.9 \\
\hline $\mathrm{S}=\mathrm{O}$ & 1045.5 & 1041.6 \\
\hline $\mathrm{O}-\mathrm{H}$ & 3421.8 & 3421.8 \\
\hline $\mathrm{N}-\mathrm{H}$ & 3500.2 & 3500.2 \\
\hline
\end{tabular}

Appearance: All the formulations were opaque odourless and had smooth appearance.

\section{Colour:}

Carbopol Hibiscus Emulgel formulations were light brown in colour.

HPMC Hibiscus Emulgel formulations were brown colour.

$\mathrm{Na} \mathrm{CMC}$ Hibiscus Emulgel formulations were dark brown in colour.

The formulations were analyzed for the homogeneity, $\mathrm{pH}$, drug content and spreadability and from the obtained results it can be observed that the Emulgel formulations were found to be stable at different temperature conditions.

Table no XV: Homogeneity, $\mathrm{pH}$, drug content and spreadability determination of emulgels

\begin{tabular}{|c|c|c|c|c|}
\hline $\begin{array}{c}\text { Formulation } \\
\text { code }\end{array}$ & Homogeneity & $\mathbf{p H}$ & $\begin{array}{c}\text { Drug } \\
\text { Content }\end{array}$ & $\begin{array}{c}\text { Spreadabilit } \\
\mathbf{y}(\mathbf{c m})\end{array}$ \\
\hline LPEG-1 & ++ & $6.8 \pm 0.03$ & $91.1 \pm 0.02$ & $1.8 \pm 0.10$ \\
\hline LPEG-2 & ++ & $6.9 \pm 0.01$ & $93.8 \pm 0.03$ & $1.6 \pm 0.08$ \\
\hline LPEG-3 & ++ & $6.8 \pm 0.06$ & $94.2 \pm 0.02$ & $2.8 \pm 0.4$ \\
\hline LPEG-4 & ++ & $6.9 \pm 0.1$ & $95.36 \pm 0.01$ & $3.1 \pm 0.3$ \\
\hline LPEG-5 & ++ & $6.8 \pm 0.12$ & $92.9 \pm 0.06$ & $3.0 \pm 0.3$ \\
\hline LPEG-6 & ++ & $6.7 \pm 0.1$ & $72.8 \pm 0.0$ & $1.2 \pm 0.02$ \\
\hline LPEG-7 & ++ & $6.8 \pm 0.02$ & $67.6 \pm 0.01$ & $1.5 \pm 0.08$ \\
\hline LPEG-8 & ++ & $6.7 \pm 0.18$ & $77.8 \pm 0.07$ & $2.2 \pm 0.1$ \\
\hline LPEG-9 & ++ & $6.8 \pm 0.02$ & $72.2 \pm 0.04$ & $2.6 \pm 0.18$ \\
\hline LPEG-10 & ++ & $6.8 \pm 0.01$ & $75.8 \pm 0.05$ & $1.1 \pm 0.02$ \\
\hline LPEG-11 & ++ & $6.8 \pm 0.02$ & $68.2 \pm 0.04$ & $1.8 \pm 0.03$ \\
\hline
\end{tabular}


B. Mounika ${ }^{1}$, International Journal of Ayurvedic \&Herbal Medicine 9(2) Mar.-Apr. 2019 (3464-3476)

\begin{tabular}{|c|c|c|c|c|}
\hline LPEG-12 & ++ & $6.5 \pm 0.08$ & $71.5 \pm 0.06$ & $2.1 \pm 0.12$ \\
\hline LPEG-13 & ++ & $6.7 \pm 0.09$ & $76.2 \pm 0.05$ & $2.4 \pm 0.16$ \\
\hline CEG-1 & ++ & $6.8 \pm 0.02$ & $83.5 \pm 0.09$ & $1.7 \pm 0.09$ \\
\hline CEG-2 & ++ & $6.8 \pm 0.03$ & $85.1 \pm 0.03$ & $1.9 \pm 0.06$ \\
\hline CEG-3 & ++ & $6.9 \pm 0.18$ & $87.4 \pm 0.05$ & $2.0 \pm 0.12$ \\
\hline CEG-4 & ++ & $6.8 \pm 0.12$ & $81.5 \pm 0.06$ & $2.8 \pm 0.15$ \\
\hline CEG-5 & ++ & $6.8 \pm 0.1$ & $79.6 \pm 0.06$ & $3.0 \pm 0.16$ \\
\hline CEG-6 & ++ & $6.1 \pm 0.01$ & $68.6 \pm 0.04$ & $1.6 \pm 0.06$ \\
\hline CEG-7 & ++ & $6.9 \pm 0.11$ & $72.2 \pm 0.06$ & $1.2 \pm 0.12$ \\
\hline CEG-8 & ++ & $6.1 \pm 0.08$ & $78.6 \pm 0.08$ & $1.8 \pm 0.08$ \\
\hline CEG-9 & ++ & $6.7 \pm 0.06$ & $76.6 \pm 0.07$ & $2.1 \pm 0.12$ \\
\hline CEG-10 & ++ & $6.8 \pm 0.02$ & $84.5 \pm 0.08$ & $2.6 \pm 0.18$ \\
\hline CEG-11 & ++ & $6.8 \pm 0.12$ & $79.8 \pm 0.05$ & $1.2 \pm 0.06$ \\
\hline CEG-12 & ++ & $6.7 \pm 0.09$ & $68.9 \pm 0.04$ & $1.6 \pm 0.12$ \\
\hline CEG-13 & ++ & $6.8 \pm 0.02$ & $77.7 \pm 0.06$ & $1.2 \pm 0.02$ \\
\hline OEG-1 & ++ & $6.9 \pm 0.09$ & $85.5 \pm 0.06$ & $1.7 \pm 0.17$ \\
\hline OEG-2 & ++ & $7.0 \pm 0.1$ & $87.2 \pm 0.08$ & $1.8 \pm 0.18$ \\
\hline OEG-3 & ++ & $7.1 \pm 0.2$ & $92.6 \pm 0.07$ & $1.6 \pm 0.12$ \\
\hline OEG-4 & ++ & $7.2 \pm 0.2$ & $97.28 \pm 0.08$ & $3.2 \pm 0.31$ \\
\hline OEG-5 & ++ & $7.0 \pm 0.08$ & $95.3 \pm 0.07$ & $2.8 \pm 0.14$ \\
\hline OEG-6 & ++ & $6.9 \pm 0.09$ & $68.5 \pm 0.05$ & $2.9 \pm 0.16$ \\
\hline OEG-7 & ++ & $6.8 \pm 0.03$ & $68.6 \pm 0.06$ & $2.1 \pm 0.12$ \\
\hline OEG-8 & ++ & $6.9 \pm 0.06$ & $71.2 \pm 0.07$ & $1.2 \pm 0.09$ \\
\hline OEG-9 & ++ & $6.2 \pm 0.01$ & $62.8 \pm 0.06$ & $1.6 \pm 0.06$ \\
\hline
\end{tabular}

Viscosity:Viscosity determinations of the prepared formulations were carried out by Brookfield Synchroelectric viscometer (LV-DV Pro II), Spindle S64 (Small sample adapter) and the angular velocity increased from 5, 10, 50, and 100rpm and values were noted and represented in the table no XVI all the formulations results were noted and it represented in the best selected formulations.

\begin{tabular}{|l|l|l|l|l|}
\hline Emulgel & At 5 rpm (cps) & At 10 rpm (cps) & At 50 rpm (cps) & At 100 rpm (cps) \\
\hline LPEG-4 & 6953 & 4183 & 1172 & 439 \\
\hline CEG-3 & 5136 & 3648 & 1245 & 462 \\
\hline OEG-4 & 9842 & 5962 & 1829 & 1081 \\
\hline
\end{tabular}

The percentage drug release of best selected formulations, all formulations results were noted and it represented in the best selected formulations.

\begin{tabular}{|c|c|c|c|}
\hline Time (Hrs) & \%DR of LPEG4 & \%DR of CEG3 & \% DR of OEG4 \\
\hline 0 & 0 & 0 & 0 \\
\hline 30 & 5.85 & 6.72 & 8.82 \\
\hline 45 & 10.61 & 12.88 & 13.58 \\
\hline 1 & 17.85 & 19.36 & 28.78 \\
\hline 2 & 34.68 & 31.18 & 41.18 \\
\hline 3 & 46.41 & 42.06 & 54.48 \\
\hline 4 & 58.21 & 59.89 & 71.18 \\
\hline
\end{tabular}




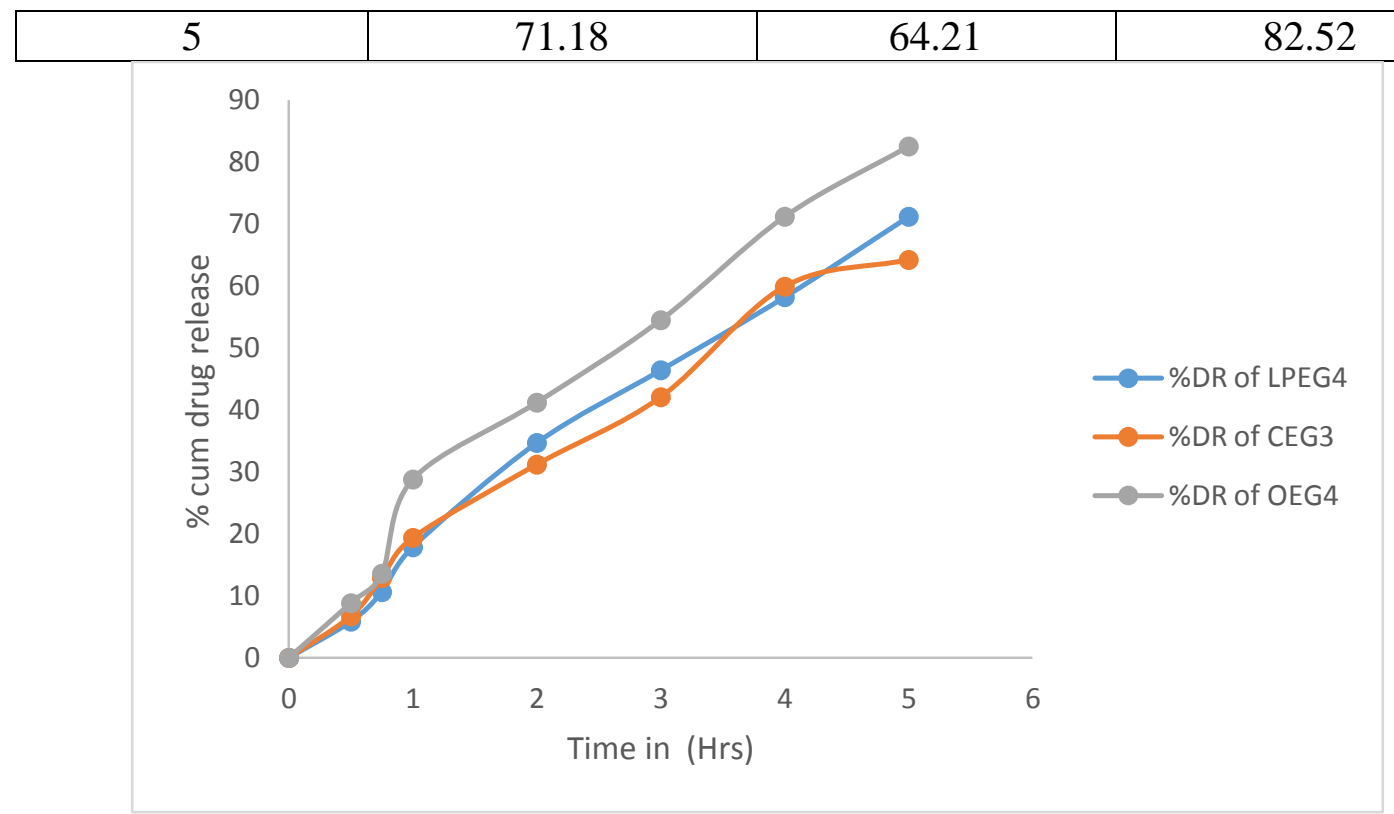

The $\%$ drug release of the final optimized emulgel (OEG 4) was found to be $82.5 \%$ within 5 hours.

Stability studies:Stability studies were performed as per ICH guidelines two different temperatures for 3 months i.e., room temperature $\left(25 \pm 2^{\circ} \mathrm{C} / 60+5 \% \mathrm{RH}\right)$ and $\left(40 \pm 2^{\circ} \mathrm{C} / 75+5 \% \mathrm{RH}\right)$. The drug content of the optimized formulation OEG4 was monitored for a period of 90days.

\begin{tabular}{|c|c|c|}
\hline $\begin{array}{l}\text { Time period } \\
\text { (days) }\end{array}$ & $\begin{array}{l}\text { \% Drug content at room temperature } \\
\text { conditions }\left(25 \pm 2^{0} \mathrm{C} / 60+5 \% \mathrm{RH}\right)\end{array}$ & $\begin{array}{l}\text { \% Drug content at room temperature } \\
\text { conditions }\left(40 \pm 2^{0} \mathrm{C} / 75+5 \% \mathrm{RH}\right)\end{array}$ \\
\hline 0 & 98.68 & 98.21 \\
\hline 30 & 96.18 & 96.62 \\
\hline 60 & 95.41 & 95.48 \\
\hline 90 & 97.16 & 97.42 \\
\hline
\end{tabular}

\section{Anti-inflammatory activity:}

\section{Acute skin irritation study for topical formulations:}

Skin irritation test was performed following OECD guidelines 404. In skin irritation test, total 9 rats were taken of either sex weighing between 180-250 gms. Animals were divided into three groups of 3 each. Hairs were depleted from the back of the rats with the help of depilatories and area $4 \mathrm{~cm}^{2}$ was marked on both the sides. One side served as control while the other as test. Test substance of $50 \mathrm{gms}$ was applied and the substance should be attached to the skin. The animals were observed for 14 days for signs of oedema and erythema.

\section{Animals:}

Male Wistar rats weighing about 180-250 gms were obtained from National Institute of Nutrition, Hyderabad. They were kept in quarantine for acclimatization in the animal cages of animal house of Sri Venkateshwara College of Pharmacy at ambient temperature of $22^{0} \mathrm{C}+2^{0} \mathrm{C}$ and relative humidity with 12 $\mathrm{hr}$ each of dark and light cycles, were fed pelleted diet and water ad libitum. The experimental protocol was duly approved by IAEC (Institutional Animal Ethical Committee) of CPCSEA (Committee for purpose of control and supervision of Experimentation on animals) through its reference no: IAEC/SVCP/2018/03. Date:28/09/18.

\section{Experimental design:}

The animals were divided into three groups 


\section{B. Mounika1, International Journal of Ayurvedic \&Herbal Medicine 9(2) Mar.-Apr. 2019 (3464-3476)}

Group I: Control

Group II: Standard Diclofenac gel

Group III: Test (Emulgel)

Investigations of anti-inflammatory activity by carrageenan induced rat paw edema method:

In the present study, approximately $50 \mu \mathrm{l}$ of a $1 \%$ suspension of carrageenan in saline was prepared $1 \mathrm{hr}$ before experiment and was injected into the plantar surface of the right hind paw of rat. To the test groups 0.2 gms of FN1, FN2 and FN3 containing methanolic extract of M.indicawas applied to the plantar surface of the right hind paw by gently rubbing with the index finger. Rats of the control group received only the gel base; Diclofenac gel which was used as a standard was applied in the same way. One hour after the application of the gel base, topical preparation of M.indica and standard; $50 \mu \mathrm{l}$ of a $1 \%$ suspension of carrageenan in saline was administered into plantar surface of the right hind paw of rat. Paw volume was measured immediately after carrageenan injection at $1 \mathrm{hr}, 2 \mathrm{hrs}, 3 \mathrm{hrs}$ and $4 \mathrm{hrs}$ by using Plethysmometer. ${ }^{[10]}$ The paw volume was recorded at different time points. The percentage inhibition in paw volume was calculated by using the formula:

$\%$ Inhibition $=\underline{\text { Paw volume (control)- Paw volume (test) }} \times 100$

\section{Paw volume (control)}

Statistical analysis: The results of studies were expressed as mean \pm SEM. Data analysis was done by oneway analysis of variance (ANOVA). Probability values $\mathrm{P}<0.01$ were considered significant when compared to control group.

Table no.4.16 \% Inhibition of paw edema

\begin{tabular}{|c|c|c|c|c|}
\hline S. No & $\begin{array}{c}\text { Time } \\
\text { in Hrs }\end{array}$ & \multicolumn{3}{|c|}{ \% Inhibition of edema } \\
\hline & & Control (without drug) & Standard (Diclofenac gel) & Test (Hibiscus Emulgel) \\
\hline 1 & 1 & 24.32 & 32.13 & 25.28 \\
\hline 2 & 2 & 29.16 & 59.51 & 56.04 \\
\hline 3 & 3 & 32.21 & 76.55 & 76.35 \\
\hline 4 & 4 & 36.47 & 94.2 & 85.46 \\
\hline
\end{tabular}

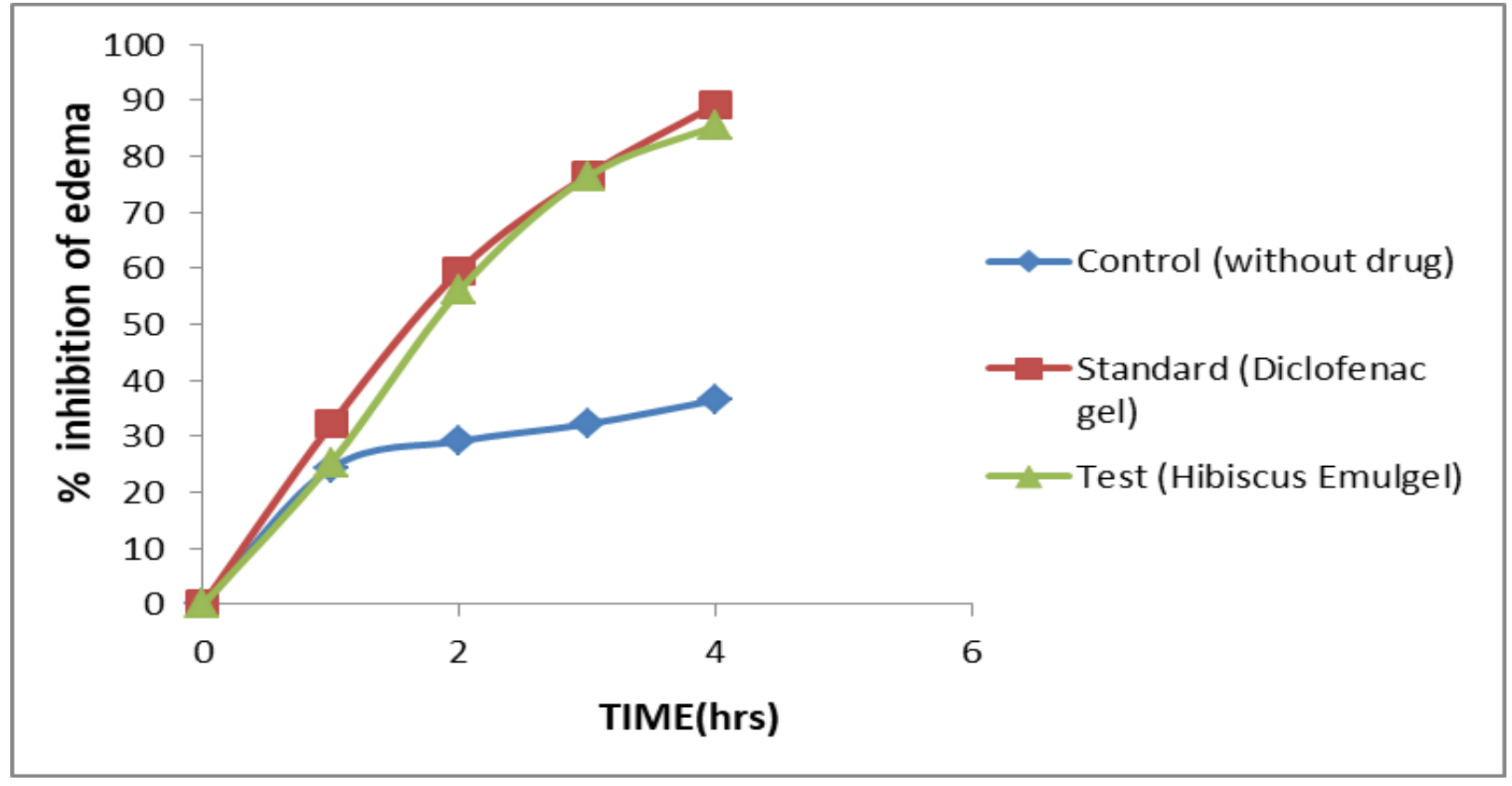




\section{B. Mounika1, International Journal of Ayurvedic \&Herbal Medicine 9(2) Mar.-Apr. 2019 (3464-3476)}

Results: The inhibition of paw edema of control, test and standard was calculated statistically using one way ANOVA. In optimized Hibiscus Emulgel the maximum inhibition was $85.46 \%$ observed at $4 \mathrm{hrs}$ of emulgel administration there was statistically significant reduction in paw edema with standard emulgel and test gel with $\mathrm{p}<0.01$. From the results it is concluded that anti-inflammatory activity of Hibiscus emulgel (OEG4) has inhibition effect as par with the standard Diclofenac gel.

\section{CONCLUSION}

Medicinal plants in plant kingdom are the important source of drug and plays a greater role for the health of individual and communities. Many plants have been tested for the presence of compounds with therapeutic activity. The present study demonstrated that the Hibiscus herbal emulgel formulation possess significant topical anti-inflammatory properties. This supports the traditional use of Hibiscus emulgel for the treatment of Inflammation.

\section{ACKNOWLEDGEMENT}

Authors are thankful to Principal Dr. Bhagavan Raju, Sri Venkateshwara College of Pharmacy, for support, encouragement and providing facilities to carry out the work.

\section{Authors contributions}

All authors have contributed equally.

\section{REFERENCES:}

1. Abbas A.B and Lichtman A.H. Chapter 2 Innate immunity. Brain Immunology. Functions and disorders of the immune system. ISBN 3ed. 2009; 978(1): 4160-4688.

2. Mohini P, Parag K, Shailesh K, Meghana L, Sanlhah B, Pravin C. Evaluation of anti-inflammatory activity of herbal gel formultion. J.Nat.prod.Plant Resource; 2011;1(2):25-28.

3. J L Knee et al., Pharmacology; A Nursing process approach, $5^{\text {th }}$ ed., Singapore: Elsevier publications. 2006.

4. DivyaJyothi, Marina K. Formulation and evaluation of an herbal anti-inflammatory gel containing TrigonellaFoenumGreacum seed extract.Int J Pharm Sci, 2016; 8(1) :41-44.

5. Parag A. Kulkarni, Shailesh K, MeghanaDhande, Mohini. A Phamse, Pravin D Chowdari. Der Pharm Chemica, 2010; 2(3): 338-342.

6. Vijay Kumar KS, Parthiban S, Senthil GPK, Tamiz TM. Ethosomes-A new trend in vescular approaches for topical drug delivery. Asian J. of Res Pharm Sci and Biotech. 2014; 2(1): 23-30.

7. Jordan SA, DG Cunningham, RJ Marles. Assessment of herbal medicinal products: Challenges and opportunities to increase the knowledge base for safety assessment. Toxicology and applied Pharmacology. 2010; 243:198-16.

8. Ajila C M, Prasad Rao U J. Protection against hydrogen peroxide induced oxidative damage in rat erythrocytes by Mangiferaindica L. peel extract. Food chemical toxicology. 2008; 46(1): 303-309.

9. B. R. Srinivas Murthy et al. Formulation and in vitro Evaluation of Liposomes loaded with Mupirocin, International Journal of Research in Pharmaceutical and Nano Sciences,4(3), 2015, 162-174.

10. Winter CA, Risley EA, Nuss GW. Carrageenan-induced edema in the hind paw of rat as an assay for anti-inflammatory activity. Proc SocExpBiol Med 1962; 111:544-7.

11. Rodriguez J, Di-pierro D, Gioia M. Effects of natural extracts from Mangiferaindica L and its active compound, mangiferin, on energy state and lipid peroxidation of red blood cells. Biochemical Biophysics. 2006; 1760 (9): 1333-42. 
B. Mounika ${ }^{1}$, International Journal of Ayurvedic \&Herbal Medicine 9(2) Mar.-Apr. 2019 (3464-3476)

12. Ali, M.K., Ashraf, A., Biswas, N.N., Karmakar, U.K. and Afroz, S., 2011. Antinociceptive, antiinflammatory and antidiarrheal activities of ethanolic calyx extract of Hibiscus sabdariffa Linn.(Malvaceae) in mice. Zhong xi yijie he xuebao= Journal of Chinese integrative medicine, 9(6), pp.626-631.

13. Chaurasiya, N. and Chakraborthy, G., 2014. Formulation and evaluation of herbal hydro gel from Hibiscus rosa-sinensis. Int J Curr Pharm Res, 6(1), pp.14-16.

14. Dafallah, A.A. and Al-Mustafa, Z., 1996. Investigation of the anti-inflammatory activity of Acacia nilotica and Hibiscus sabdariffa. The American journal of Chinese medicine, 24(03n04), pp.263-269.

15. Guddeti, V., Babu, D.M., Nagamani, B., Teja, M.R., Sravani, M.S. and Spandana, C.H., 2015. Evalutionof anti-inflammatory activity of Hibiscus rosasinensislinn. Flower extract in rats. International Journal of Pharmaceutical, Chemical \& Biological Sciences, 5(3).

16. Narender, K.S., Kumar, D. and Kumar, V., 2009. Antinociceptive and anti-inflammatory activity of Hibiscus tiliaceus leaves. International Journal of Pharmacognosy and Phytochemical Research, 1(1).

17. Sultana, S., Al Faruq, A., Nahid-Al-Rashid, D., Nasim, T. and Ahsan, M.Q., In-vitro antiinflammatory, anti-oxident and in-vivo analgesic, anti-diarrhel activities of fractional leaf extracts of Hibiscus surattensis.

18. Tomar, V., Kannojia, P., Jain, K.N. and Dubey, K.S., 2010. Antinoceceptive and anti-inflammatory activity of leaves of Hibiscus-rosasinensis. International Journal of Research in Ayurveda \& Pharmacy, 1(1), pp.201-205.

19. Zhen, J., Villani, T.S., Guo, Y., Qi, Y., Chin, K., Pan, M.H., Ho, C.T., Simon, J.E. and Wu, Q., 2016. Phytochemistry, antioxidant capacity, total phenolic content and anti-inflammatory activity of Hibiscus sabdariffa leaves. Food chemistry, 190, pp.673-680.

20. Indira S, Priyanka R, Prathima S. Formulation and evaluation of ethosomal topical gels of Etoricoxib. International Journal for Pharmaceutical Research Scholars. 2015; 4(1): 93-103.

21. Esayed M M, Abdallah O Y, Naggar V F, Khalafallah N M. Lipid vesicles for skin delivery reviewing three decades of research. International journal of Pharmaceutics. 2007; 332: 1-16.

22. Winter CA, Risley EA, Nuss GW. Carrageenan-induced edema in the hind paw of rat as an assay for anti-inflammatory activity. Proc SocExpBiol Med 1962; 111:544-7 